\title{
Improvement of geotechnical properties of silty sand soils using natural pozzolan and lime
}

\author{
Nader Abbasi ${ }^{1 *}$ [D and Masoud Mahdieh²
}

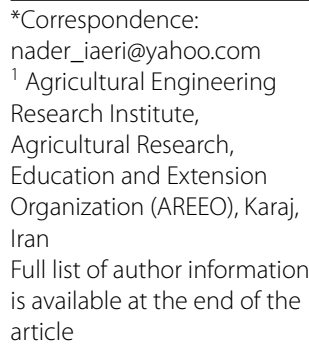

\begin{abstract}
In this study the effect of different amounts of lime and natural pozzolan on geotechnical properties of a silty sand soil has been investigated. To do this, 20 treatments were prepared with adding five lime levels of 0, 1, 3, 5 and 7\% (by weight) and four levels of pozzolan including; 0, 5, 10 and 15\%. Compaction characteristics, compressive strength and bearing capacity of the treatments were determined using standard test procedures. For evaluation of compressive strength, cylindrical specimens $(3.5 \mathrm{~cm}$ in diameter and $7 \mathrm{~cm}$ in length) were made and cured for three different ages including 7, 14 and 28 days in three replication. Result of compaction tests showed that adding of both lime and pozzolan alone and with together increase optimum moisture content and decrease the maximum dry density of treated soil samples. Statistical analysis using SPSS software showed that although adding of natural pozzolan and lime to the soil increases the compressive strength significantly, but adding of them with together is more effective. So that the compressive strength of a treatment having $3 \%$ lime and $15 \%$ pozzolan was found to be 16 times of untreated sample. Furthermore, the results of California Bearing Ratio, CBR test showed that the values of CBR in different treatment increased up to 12 times of untreated sample.
\end{abstract}

Keywords: Silty sand soil, Compressive strength, Natural pozzolan, Lime, CBR

\section{Introduction}

Soil stabilization is a general term used for any of the physical, chemical, or biological methods, or a combination of them, which is used to improvement of soil properties [17]. Improvement of soil engineering properties is an inevitable necessity, when the structures are founded on a problematic soils. Expansive, collapsible, liquefiable, soluble, dispersive, silty fine sands, and highly organic weak soils are the most serious kinds of problematic soils $[1,2,6]$. Silty sand soils are kinds of the problematic soils which found in different areas of the world and are susceptible to collapse when come in contact with water.

Soil improvement can be undertaken by a variety of ground improvement techniques such as compaction, reinforcement, drainage, and addition of natural and synthetic materials or a combination of physical and chemical methods $[4,16]$. Chemical stabilization or addition of different natural and synthetic material to the soil has been experienced in recent years. Lime, cement and pozzolanic materials are the most common

(c) The Author(s) 2018. This article is distributed under the terms of the Creative Commons Attribution 4.0 International License (http://creativecommons.org/licenses/by/4.0/), which permits unrestricted use, distribution, and reproduction in any medium, provided you give appropriate credit to the original author(s) and the source, provide a link to the Creative Commons license, and indicate if changes were made. 
construction materials which are extensively used for stabilization of soils. Recently different modern technologies such as nanoparticles were used for stabilization of the soils [3]. Sakr et al. [18] studied the geotechnical and mineralogical properties of a lime treated high organic soft clay soil and showed that with increasing the curing age and lime percent, unconfined compressive strength increases. Furthermore, the required lime content for satisfactorily stabilization of the high organic soft clay was found to be $7 \%$. Amer et al. [7] showed that with the addition of $6 \%$ lime, both the swell percent and swell pressure reduced to zero. Rabbani et al. [15] evaluated the use of Grand Granulated Blast Furnace Slag (GGBFS) and lime in stabilizing desert silty sand for possible use in geotechnical engineering applications, especially for roadways and railways constructions. Results indicated that the swelling behavior of mixtures was decreased effectively. Thus mixture of GGBFS and lime can be suggested to improve engineering characteristic of desert silty sands. Ji-ru and Xing [11] investigated the individual and admixed effects of lime and fly ash on the geotechnical characteristics of expansive soil. The results of experiment showed that as the amount of lime and fly ash is increased, there is an apparent reduction in maximum dry density, free swell and swelling capacity under $50 \mathrm{kPa}$ pressure, and a corresponding increase in the percentage of coarse particles, optimum moisture content and CBR value. Mohamedzein et al. [13] presented that the engineering properties of the desert sands can be improved significantly by the addition of incinerator ash. Saltan and Findik [19] used the pumice of the Isparta-Karakaya as stabilization material in the subbase layer and showed that pumice can be used as subbase material of highway and the stabilization material when building highway and every kind of road. Lin et al. [12] used sewage sludge ash (SSA) and hydrated lime to stabilize soft cohesive subgrade soil. To do this, five different ratios of sludge ash to hydrated lime including; $0,2,4,8$, and $16 \%$ by weight were added to the cohesive soil. The results indicated that the unconfined compressive strength of treated specimens increased from three to seven times. Also, it was observed that 95\% of CBR values of treated samples were close to high bearing capacity subgrade soil materials. Zhang et al. [20] presented that lignin has a great potential to improve engineering properties of silt and shows a promising prospect as a new environmentally friendly soil stabilizer. Curing time and lignin content have significant influence on the basic engineering properties and microstructural characteristics of the lignin stabilized silt. The optimum content of lignin for foundation silt in Jiangsu Province of China is approximately $12 \%$. Bagherian et al. [9] studied the effects of rice husk ash (RHA) on Atterberg limits, compaction characteristic, shear strength and bearing capacity of soils. They showed that by adding of 4-6\% of lime and various percentages of RHA to the soil, CBR values increases significantly. Baghdadi and Rahman [8] studied the effects of cement kiln dust (CKD) on geotechnical properties of dune sand. The results of tests showed that by addition of CKD, compressive strength and CBR values increases significantly. Chen and Lin [10] mixed incinerated sewage sludge ash (ISSA) with cement in a ratio of 4:1 and added this mixture with a soft and cohesive subgrade soil in four different rates of 2, 4, 8 and 16\% They showed that unconfined compressive strength of specimens with the ISSA/cement addition improved approximately 3-7 times. In some samples, the ISSA/cement additive improved the CBR values by up to 30 times. Sewage sludge ash (SSA) is also a kind of synthetic pozzolanic materials which could be used successfully used for stabilization of 
soils [14]. In this research the effects of a natural pozzolan and lime were investigated for stabilization of a silty sand soil.

\section{Materials and methods}

\section{Preparation of the materials}

First, silty sand soil sample, pozzolan and lime were the main materials used in this research. The soil sample was provided from the road of Jandagh-Garmsar situated in central desert area of Iran. The index properties and mineralogical characteristics of the soil sample were presented in Tables 1 and 2. The Pozzolan used in this research is a natural kind of pozzolan provided from Abyek Cement Factory. The natural pozzolan was pulverized and passed from sieve No. $60(0.25 \mathrm{~mm})$. Also the lime was provided from Qom Lime Factory as hydrated form. X-ray diffraction (XRD) tests performed in order to determine the minerals of lime and pozzolan, as presented in Table 3. The gradation curves of the powdered pozzolan and studied soil are shown in Fig. 1.

Table 1 Index properties of the soil sample

\begin{tabular}{lllll}
\hline Soil classification & Specific gravity & $\begin{array}{l}\text { Maximum dry } \\
\text { density }\left(\mathbf{g} / \mathbf{c m}^{\mathbf{3}}\right)\end{array}$ & $\begin{array}{l}\text { Optimum moisture } \\
\text { content (\%) }\end{array}$ & Plasticity \\
\hline SM & 2.52 & 2.01 & 9.96 & N.P. \\
\hline
\end{tabular}

Table 2 Mineralogy of the soil sample

\begin{tabular}{llllll}
\hline $\mathrm{CaSO}_{\mathbf{4}}, \mathbf{2 H}_{\mathbf{2}} \mathbf{O}$ & $\mathrm{SiO}_{\mathbf{2}}$ & $\mathrm{CaCO}_{\mathbf{3}}$ & $\mathrm{NaAlSi}_{\mathbf{3}} \mathrm{O}_{\mathbf{8}}$ & $\mathrm{KAISi}_{\mathbf{3}} \mathbf{O}_{\mathbf{8}}$ & $(\mathbf{M g}, \mathrm{Fe})_{\mathbf{6}}$ \\
\hline 25 & 23 & 20 & 20 & 5 & 2
\end{tabular}

Table 3 Percentage of minerals in the additives

\begin{tabular}{lrrlllll}
\hline & $\mathbf{S i O}_{\mathbf{2}}$ & $\mathbf{A l}_{\mathbf{2}} \mathbf{O}_{\mathbf{3}}$ & $\mathbf{F}_{\mathbf{e}} \mathbf{2 O}_{\mathbf{3}}$ & $\mathbf{C a O}$ & $\mathbf{M g O}$ & $\mathbf{S O}_{\mathbf{3}}$ & $\mathbf{K}_{\mathbf{2}} \mathbf{O}$ \\
\hline Lime & 1.36 & 0.24 & 0.13 & 51.64 & 2.65 & 0.8 & 0.03 \\
Pozzolan & 54.87 & 18.88 & 2.62 & 2.62 & 1.93 & 0.15 & 5.5 \\
\hline
\end{tabular}

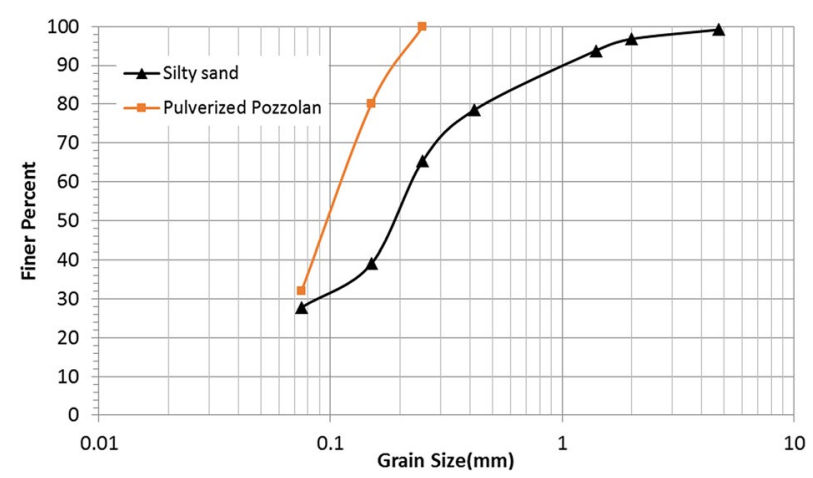

Fig. 1 The gradation curves of the studied materials 


\section{Preparation of the treatments}

Considering that main purpose of the research is surveying effects of different contents of lime and pozzolan on characteristics of the soil and assessing suitable mixture for stabilization, numerous treatments were prepared and tested. For this purpose, four different levels of pozzolan including; 0, 5, 10 and 15\% by dry weight of soil and also five different levels of lime; $0,1,3,5$ and $7 \%$ were mixed to the soil and so that 20 different mixtures (treatments) were prepared. Details of the treatments were presented in Table 4.

\section{Laboratory tests}

Unconfined compressive strength and California Bearing Ratio, CBR, tests were used for assessing the mechanical behavior and characteristic of the treated specimens. Harvard miniature compaction test apparatus having $3.1 \mathrm{~cm}$ in diameter by $7.1 \mathrm{~cm}$ height was used for construction of unconfined compressive strength test specimens. To do this, standard compaction test, according to ASTM D1557-02, was performed to determine the maximum dry density (MDD) and optimum moisture content (OMC) of the treated soil samples. Then treated soils containing OMC were placed in the mold at 5 equal layers and each layer was compacted with 16 impacts of standard hammer. Figure 2a shows Harvard miniature compaction test apparatus and prepared cylindrical specimens. Then, the specimens were cured in plastic bag for 7, 14, and 28 days. Considering 3 replication for each treatment and 3 different curing ages, totally 180 test specimens were prepared and tested with a constant speed rate uniaxial test apparatus as shown in Fig. 2b. CBR tests were done in accordance with ASTM D1883-99 on different treatments at curing age of 14 days and under 2 different moisture condition of optimum moisture content

Table 4 Detailed specification of the treatment

\begin{tabular}{|c|c|c|c|}
\hline No. of treatment & Sign of treatment & Pozzolan contents (\%) & Lime contents (\%) \\
\hline 1 & POLO & 0 & 0 \\
\hline 2 & POL1 & 0 & 1 \\
\hline 3 & P0L3 & 0 & 3 \\
\hline 4 & POL5 & 0 & 5 \\
\hline 5 & POL7 & 0 & 7 \\
\hline 6 & P5L0 & 5 & 0 \\
\hline 7 & P5L1 & 5 & 1 \\
\hline 8 & $P 5 L 3$ & 5 & 3 \\
\hline 9 & P5L5 & 5 & 5 \\
\hline 10 & P5L7 & 5 & 7 \\
\hline 11 & P10L0 & 10 & 0 \\
\hline 12 & P10L1 & 10 & 1 \\
\hline 13 & P10L3 & 10 & 3 \\
\hline 14 & P10L5 & 10 & 5 \\
\hline 15 & P10L7 & 10 & 7 \\
\hline 16 & P15L0 & 15 & 0 \\
\hline 17 & P15L1 & 15 & 1 \\
\hline 18 & P15L3 & 15 & 3 \\
\hline 19 & P15L5 & 15 & 5 \\
\hline 20 & P15L7 & 15 & 7 \\
\hline
\end{tabular}



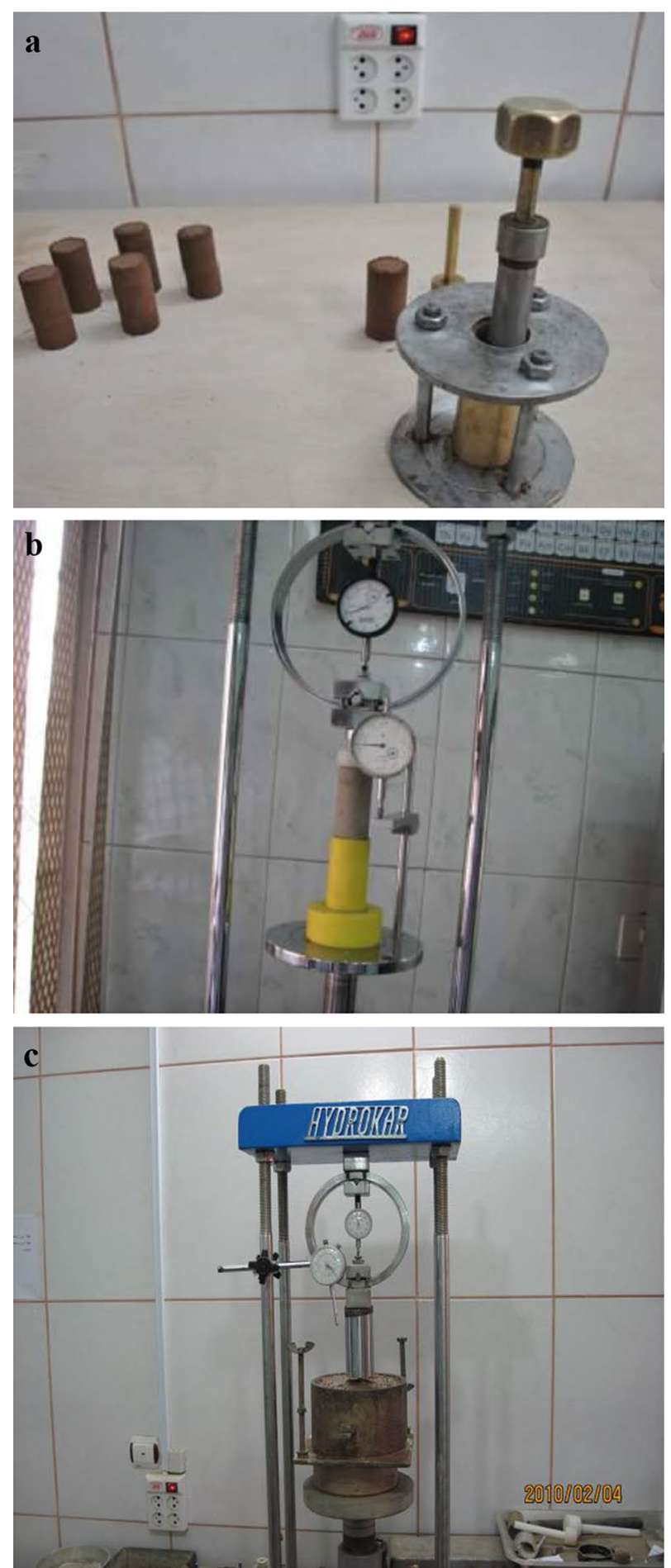

Fig. 2 Apparatuses used in this study: a harvard miniature compaction test apparatus, b unconfined compressive strength, c CBR test apparatus 
and saturated. For the last condition, the CBR specimens were saturated for 4 days under $5.8 \mathrm{~kg}$ overburden pressure after curing time. The swelling of specimens was negligible to start the test so the samples were fixed in loading setting and penetration was carried out with a rate of $1.25 \mathrm{~mm} / \mathrm{min}$. Figure 2c shows CBR test apparatus used in this study.

\section{Results and discussion}

\section{Compaction tests}

As mentioned in previous section, standard compaction test was performed in order to determine the effect of lime and pozzolan on optimum water content and maximum dry density of treated soils. Figures 3 and 4 show the effects of pozzolan on OMC and lime on MDD of treated soil samples typically. It was found that the optimum moisture content, OMC, of the samples increases and maximum dry density, MDD, decreases as pozzolan and lime content increases. By increasing the amounts of additives, which is very finer than silty sand soil, the treated sample tend to be finer and having bigger void ratio and thereby causes the increasing of OMC. Increasing of OMC will always lead to decrease the maximum dry density as the specific gravity of soil and additives particles
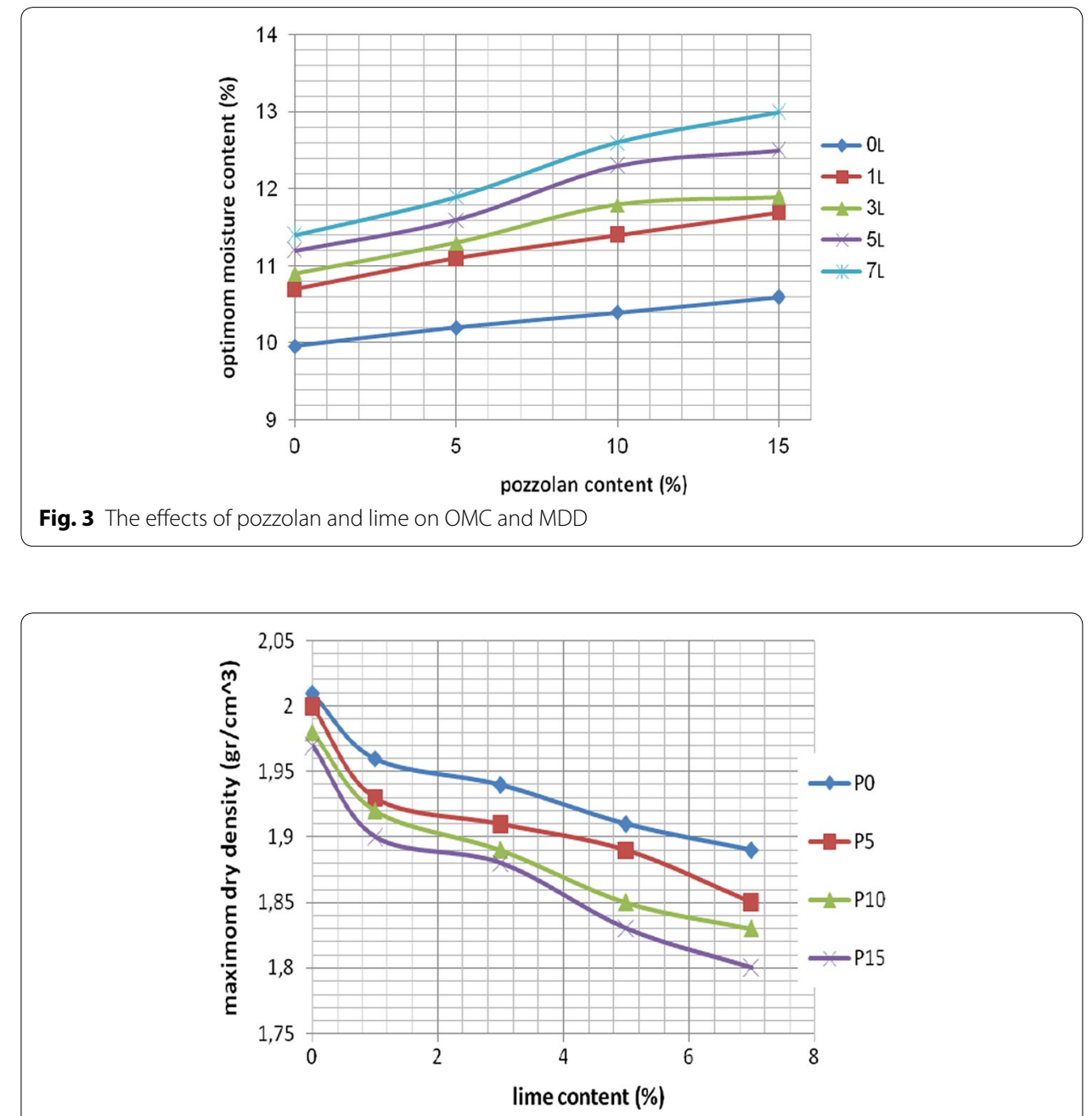

Fig. 4 The effects of lime on MDD 
are more than water. In the performed tests the value of OMC, increases from $9.96 \%$ for natural soil to $13 \%$ for P15L7 treatment. This finding confirms the earlier findings of different researchers (e.g. [5]).

\section{Unconfined compressive strength test}

The variations of unconfined compressive strength of different treatment at different curing times are presented in Table 5. Also the variations of unconfined compressive strength versus lime and pozzolan contents are illustrated in Figs. 5 and 6, respectively.

Table 5 Unconfined compressive strength of different treatment at different curing times

\begin{tabular}{|c|c|c|c|}
\hline \multirow[t]{2}{*}{ Treatment no. } & \multicolumn{3}{|c|}{ Unconfined compressive strength $\left(\mathrm{kg} / \mathrm{cm}^{2}\right)$} \\
\hline & 7-day & 14-day & 28-day \\
\hline$P 0+L 0$ & 1.07 & 1.07 & 1.07 \\
\hline$P 0+L 1$ & 3.09 & 3.65 & 6.65 \\
\hline$P 0+L 3$ & 2.99 & 4.37 & 8.24 \\
\hline$P 0+L 5$ & 2.98 & 3.60 & 7.78 \\
\hline$P 0+L 7$ & 2.32 & 2.70 & 6.9 \\
\hline$P 5+L 0$ & 1.53 & 2.02 & 2.28 \\
\hline $\mathrm{P} 5+\mathrm{L} 1$ & 5.29 & 11.23 & 12.08 \\
\hline$P 5+L 3$ & 4.97 & 9.37 & 14.98 \\
\hline$P 5+\llcorner 5$ & 4.94 & 12.84 & 14.17 \\
\hline $\mathrm{P} 5+\mathrm{L} 7$ & 4.68 & 10.24 & 12.07 \\
\hline $\mathrm{P} 10+\llcorner 0$ & 1.79 & 2.56 & 2.92 \\
\hline $\mathrm{P} 10+\mathrm{L} 1$ & 7.11 & 11.44 & 13.04 \\
\hline $\mathrm{P} 10+\mathrm{L} 3$ & 4.87 & 13.15 & 13.38 \\
\hline$P 10+\llcorner 5$ & 3.83 & 11.82 & 16.22 \\
\hline $\mathrm{P} 10+\mathrm{L7}$ & 4.44 & 13.57 & 14.05 \\
\hline $\mathrm{P} 15+\mathrm{LO}$ & 1.39 & 2.85 & 3.05 \\
\hline P15 + L1 & 5.78 & 12.97 & 14.05 \\
\hline $\mathrm{P} 15+\mathrm{L} 3$ & 7.18 & 15.89 & 14.99 \\
\hline P15 + L5 & 5.93 & 16.57 & 16.64 \\
\hline P15 + L7 & 5.27 & 14.65 & 14.46 \\
\hline
\end{tabular}

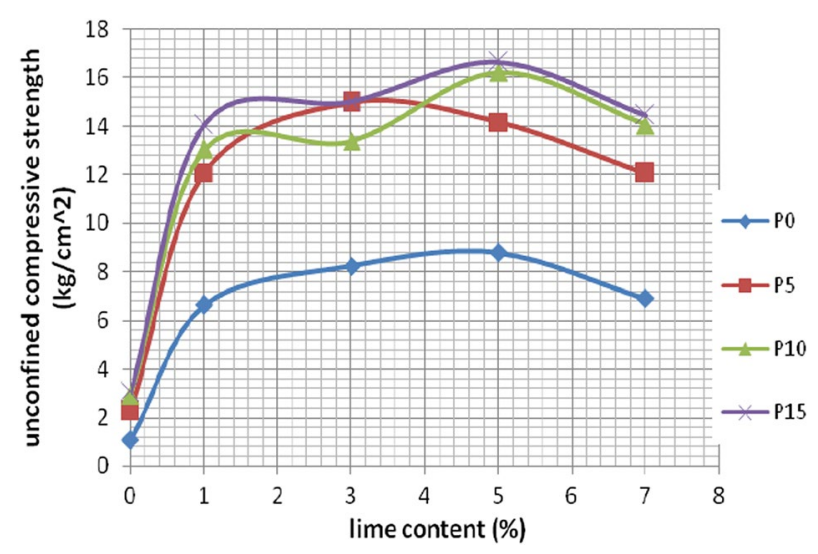

Fig. 5 Effects of lime content on compressive strength of samples having different pozzolan content 


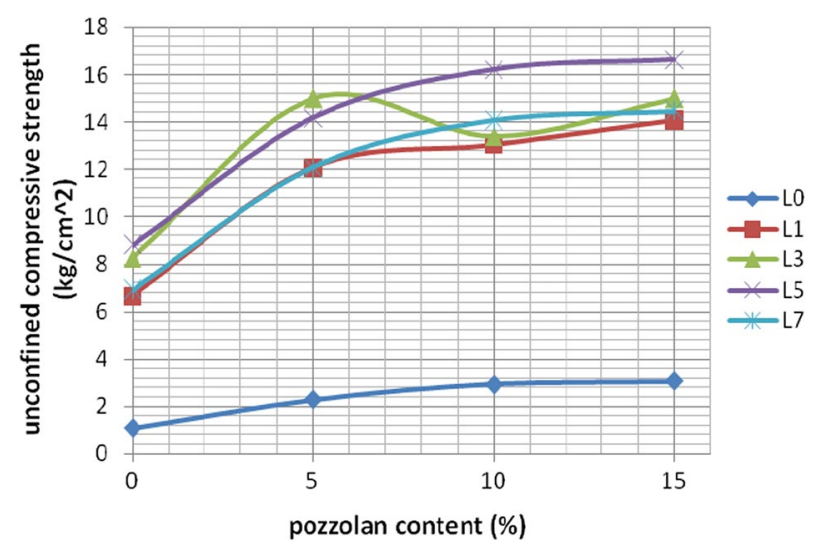

Fig. 6 Effects of pozzolan content on compressive strength of samples having different lime content

In Fig. 5, it is observed that increasing of lime content causes significant improvement in compressive strength of the soil at in all of the pozzolan contents, and the maximum strength is achieved at 5\% lime approximately. Figure 6 indicates that pozzolan without lime cannot affect the compressive strength significantly, while in the samples containing lime, increasing of pozzolan content lead to increasing of compressive strength and the maximum compressive strength increases as the pozzolan content increases.

As it is obvious from Table 5, almost in all of the treatments, by increasing the curing time, compressive strength increases while in the treatments containing only pozzolan, curing time doesn't affect the compressive strength, considerably. But in the samples containing lime, the strength of the samples is increased with curing time proportionally. Furthermore, it is found that the improvement of compressive strength in samples treated by pozzolan and lime with together is higher than those having only lime or pozzolan. It means that the application of lime and pozzolan with together is more efficient for strengthening of the silty sand soil. In addition, the rate of compressive strength growth is very high up to 2 weeks and after that it becomes gentle and even in some cases, it doesn't change.

In order to compare the effects of pozzolan and lime with curing time more precisely, the experimental data were statistically analyzed by the commonly used statistical software, SPSS. The results of statistically analysis of presented in Tables 6, 7, 8, and 9. Table 6 shows that there is no significant difference between replications at a significance level of 0.01 or with a probability level of $99 \%$. But, there is significant difference between compressive strength of treatments containing different levels of lime, pozzolan and curing ages Also, the table reveals that various parameters; i.e. lime, pozzolan and curing age; affect the compressive strength, significantly, meanwhile there exist interactions between these parameters. Tables 7, 8 and 9 show mean comparison analysis using Duncan method for assessment of the effect of Pozzolan, lime and curing ages on compressive strength of treatments.

Table 6 indicates that in various curing time, by increasing pozzolan content, compressive strength increase where, by addition $5 \%$ pozzolan the average compressive strength of the samples increases from 3.96 to $8.20 \mathrm{~kg} / \mathrm{cm}^{2}$; i.e. more than 2 times; and then after it has less influences. Table 7 shows that lime percent based on the value of compressive 
Table 6 Results of variance analysis of effects of pozzolan, lime and curing age on unconfined compressive strength

\begin{tabular}{lcc}
\hline Sources of the variations & Degree of freedom & Root mean square of compressive strength \\
\hline Replication & 2 & $0.799 \mathrm{~ns}$ \\
Pozzolan & 3 & $319.471^{* *}$ \\
Lime & 4 & $389.799^{* *}$ \\
Time & 2 & $671.210^{* *}$ \\
Pozzolan $\times$ lime & 12 & $13.457^{* *}$ \\
Pozzolan $\times$ time & 6 & $35.065^{* *}$ \\
Lime $\times$ time & 8 & $35.907^{* *}$ \\
Pozzolan $\times$ lime $\times$ time & 24 & $3.784^{* *}$ \\
Total error & 118 & $0.671 \mathrm{~ns}$ \\
Total mean $\left(\mathrm{kg} / \mathrm{cm}^{2}\right)$ & 179 & 7.803 \\
Coefficient of variation $(\%)$ & & 10.5 \\
\hline
\end{tabular}

Table 7 Effect of pozzolan content on mean of compressive strength of treatments

\begin{tabular}{llllll}
\hline Pozzolan content (\%) & Number of samples & \multicolumn{2}{l}{ Subset } & & \\
\cline { 3 - 6 } & & $\mathbf{1}$ & $\mathbf{2}$ & $\mathbf{3}$ & $\mathbf{4}$ \\
\hline 0 & 45 & 3.96 & & & \\
5 & 45 & & 8.20 & & \\
10 & 45 & & & 8.94 & \\
15 & 45 & & & & 10.06
\end{tabular}

Table 8 Effect of lime content on mean of compressive strength of treatments

\begin{tabular}{lllll}
\hline Lime content (\%) & Number of samples & \multicolumn{2}{l}{ Subset } & \\
\cline { 3 - 5 } & & $\mathbf{1}$ & $\mathbf{2}$ & $\mathbf{3}$ \\
\hline 0 & 36 & 1.97 & & \\
7 & 36 & & 8.72 & \\
1 & 36 & & 8.86 & \\
3 & 36 & & & 9.53 \\
5 & 36 & & & 9.88 \\
\hline
\end{tabular}

Table 9 Effect of curing time on mean compressive strength of all the samples

\begin{tabular}{lllll}
\hline Curing time (day) & Number of samples & \multicolumn{2}{l}{ Subset } & \\
\cline { 3 - 4 } & & $\mathbf{1}$ & $\mathbf{2}$ & $\mathbf{3}$ \\
\hline 7 & 60 & 4.05 & & \\
14 & 60 & & 8.83 & 10.50 \\
28 & 60 & & & \\
\hline
\end{tabular}

strength can be classified in three subsets: no lime, extreme values of lime (7 and 1\%) and medium lime ( 3 and $5 \%$ ). According to this classification, the lime content of $3 \%$ which is in the third subset is assigned as the optimum lime content. The point to be mentioned is that, by adding only $1 \%$ lime, average compressive strength of the samples increases 
from 1.97 to $8.86 \mathrm{~kg} / \mathrm{cm}^{2}$ there after its influences decreases significantly. Table 8 presents the compressive strength increases as the curing age increase where at 28 days, the maximum value is achieved.

\section{California Bearing Ratio tests}

As mentioned earlier, CBR tests were performed on different treatments at curing age of 14 days and under 2 moisture condition of optimum water content and saturated. The effects of pozzolan and lime contents on CBR values are presented in Figs. 7 and 8, respectively. Figure 7 shows the variation of CBR for the samples containing $5 \%$ lime and different content of pozzolan in both conditions of optimum water content and soaked after 14 days. It is clearly obvious from the Fig. 7 that the CBR values increases by increasing pozzolan content. Also, Fig. 8 indicates that in the samples containing 10\% pozzolan, CBR values increases by increasing lime percentage, whereas for lime percentages more than $5 \%$, CBR values decreases. Totally, it is revealed that by adding lime and pozzolan admixtures to the soil, CBR values increases significantly. For example; CBR values of the treatment P15 + L5 were 120 and 63 in optimum moisture and saturated conditions respectively which are 9 and 12 times of corresponding CBR value of natural

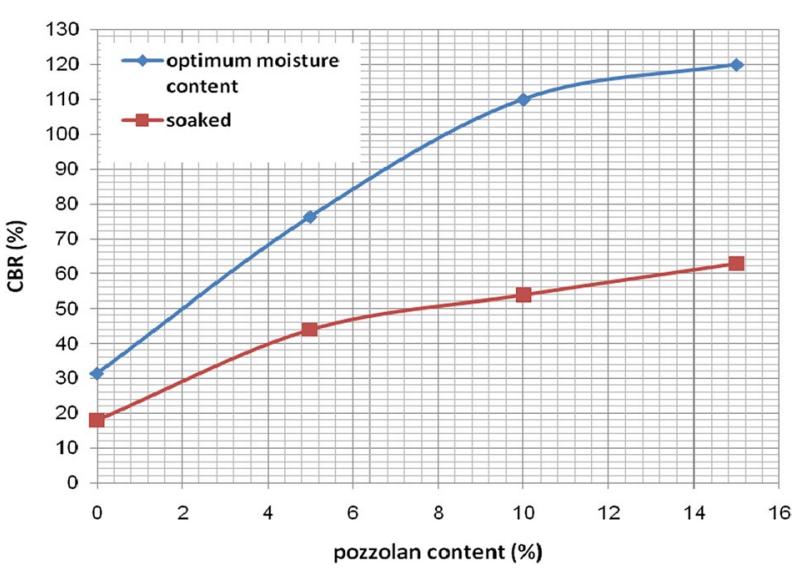

Fig. 7 Effects of pozzolan content on CBR values of samples containing 5\% lime

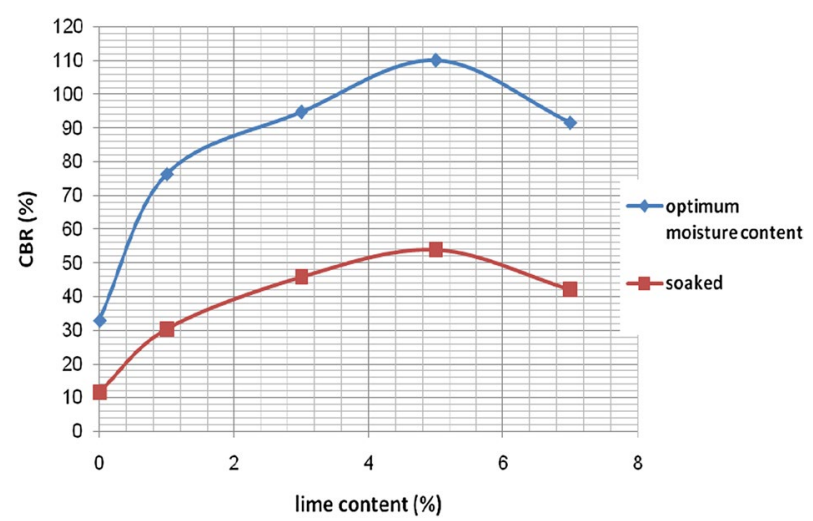

Fig. 8 Effects of lime content on CBR values of samples containing 10\% pozzolan 
soil. Also, it was found that the CBR values of saturated samples are approximately half of CBR values of those with optimum moisture content.

\section{Conclusion}

Based on the results of different tests in this research, the following conclusions could be derived:

1. Adding lime or pozzolan or both of them to a silty sand soil, causes an increase in optimum moisture content and a decrease in the maximum dry density.

2. Application of pozzolan with alone has a little or negligible effect on compressive strength of silty sand soil.

3. Adding lime to the soil, improves compressive strength while using both of lime and pozzolan, causes substantial increasing in compressive strength even to 16 times in comparison of natural soil.

4. Curing time has important role on increasing of compressive strength of treated silty sand soil with lime and pozzolan.

5. The maximum values of compressive strength were achieved by applying of $15 \%$ pozzolan and 1, 3 and 5\% lime at 7, 14 and 28 days curing respectively.

6. Adding of lime and pozzolan causes increasing of California Bearing Ratio (CBR) values up to 9 times in optimum water content condition and up to 12 times in saturated condition in comparison of the natural soil.

7. Based on the statistical analysis of the results, a combination of 3 and $15 \%$ pozzolan was found as the most effective combination for stabilization of silty sand soil.

\section{Authors' contributions}

NA conceived of the study, participated in its design and coordination, conducting of the statistical analysis and drafted the manuscript; MM participated in the design of the study and performed the measurement. Both authors read and approved the final manuscript.

\section{Author details}

${ }^{1}$ Agricultural Engineering Research Institute, Agricultural Research, Education and Extension Organization (AREEO), Karaj, Iran. ${ }^{2}$ Department of Technology and Engineering, Islamic Azad University of Central Tehran Branch, Tehran, Iran.

\section{Competing interests}

The athours declare that they have no competing interests.

\section{Ethics approval and consent to participate}

Written informed consent was obtained from the pateint for the publication of this report and any accompanying images.

\section{Publisher's Note}

Springer Nature remains neutral with regard to jurisdictional claims in published maps and institutional affiliations.

Received: 9 November 2016 Accepted: 25 January 2018

Published online: 01 February 2018

References

1. Abbasi N (2011) The role of anions in dispersion potential of clayey soil. J Agric Eng Res 12(3):15-30

2. Abbasi N, Nazifi MH (2013) Assessment and modification of sherard chemical method for evaluation of dispersion potential of soils. J Geotech Geol Eng. 31(1):337-349. https://doi.org/10.1007/s10706-012-9573-7

3. Abbasi N, Farjad A, Sepehri S (2017) The use of nanoclay particles for stabilization of dispersive clayey soils. J Geotech Geol Eng. https://doi.org/10.1007/s10706-017-0330-9

4. Abbasi N, Bahramloo R, Movahedan N (2015) Strategic planning for remediation and optimization of irrigation and drainage networks: a case study for Iran. Agric Agric Sci Procedia 4:211-221. https://doi.org/10.1016/j. aaspro.2015.03.025 
5. Abdi M, Charkhyari F (2010) Application of BOS Slug for stabilization of fine grained soils. In: 8th international congress of civil Engineering, Shiraz, Iran

6. Afsharian AA, Abbasi N, Khosrojerdi A, Sedghi H (2016) Analytical and laboratory evaluation of the solubility of Gypsiferrous soils. Civil Eng J 2(11):590-599

7. Amer AA, Hago AW, Hilal A (2004) Effect of lime, cement and Sarooj (artificial pozzolan) on the swelling potential of an expansive soil from Oman. Build Environ 40(5):681-687. https://doi.org/10.1016/j.buildenv.2004.08.028

8. Baghdadi ZA, Rahman MA (1990) The potential of cement kiln dust for the stabilization of dune sand in highway construction. J Build Environ 25(4):285-289. https://doi.org/10.1016/0360-1323(90)90001-8

9. Bagherian A, Janializade A, Hesami S (2005) The effects of rice ash and lime on bearing capacity of soils. In: 2nd congress of civil Engineering, Tehran, Iran

10. Chen L, Lin D (2009) Stabilization treatment of soft subgrade soil by sewage sludge ash and cement. J Hazard Mater 162:321-327

11. Ji-ru ZH, Xing C (2002) Stabilization of expansive soil by lime and fly ash. J Wuhan Univ Technol Mater Sci 17:4

12. Lin D, Lin K, Hung M, Luo H (2007) Sludge ash/hydrated lime on the geotechnical properties of soft soil. J Hazard Mater 145:58-64

13. Mohamedzein YEA, Al-Aghbari MY, Taha RA (2006) Stabilization of desert sands using municipal solid waste incinerator ash. Geotech Geol Eng 24:1767-1780

14. Norouzian K, Abbasi N, Abedi Koupai J (2017) Use of sewage sludge ash and hydrated lime to improve the engineering properties of clayey soils. Geotech Geol Eng. https://doi.org/10.1007/s10706-017-0411-9

15. Rabbani P, Daghigh Y, Atrechian MR, Karimi M, Tolooiyan A (2012) The potential of lime and grand granulated blast furnace slag (GGBFS) mixture for stabilisation of desert silty sands. J Civil Eng Res 2(6):108-119. https://doi. org/10.5923/i.jce.20120206.07

16. Rahimi H, Abbasi N (2008) Failure of concrete canal lining on fine sandy soils (A case study for Saveh Project). J Irrigation Drainage, ICID 57:83-92. https://doi.org/10.1002/ird.350

17. Rahimi H, Abbasi N, Shantia H (2011) Application of geomembrane to control piping of sandy soil under concrete canal lining (case study: Moghan irrigation project, Iran). J Irrig Drain Eng 60:330-337. https://doi.org/10.1002/ ird. 574

18. Sakr MA, Shahin MA, Metwally YM (2009) Utilization of lime for stabilizing soft clay soil of high organic content. Geotech Geol Eng 27:105-113

19. Saltan M, Findik SF (2008) Stabilization of subbase layer materials with waste pumice in flexible pavement. Build Environ 43(2008):415-421. https://doi.org/10.1016/j.buildenv.2007.01.007

20. Zhang T, Cai G, Liu S, Puppala Anand J (2016) Engineering properties and microstructural characteristics of foundation silt stabilized by lignin-based industrial by-product. KSCE J Civil Eng 20(7):2725-2736. https://doi.org/10.1007/ s12205-016-1325-4

\section{Submit your manuscript to a SpringerOpen ${ }^{\circ}$ journal and benefit from:}

- Convenient online submission

- Rigorous peer review

- Open access: articles freely available online

- High visibility within the field

Retaining the copyright to your article

Submit your next manuscript at $\gg$ springeropen.com 